\title{
Changes in Mortality After Massachusetts Health Care Reform
}

\section{Citation}

Sommers, Benjamin D., Sharon K. Long, and Katherine Baicker. 2014. "Changes in Mortality After Massachusetts Health Care Reform." Ann Intern Med 160 (9) (May 6): 585. doi:10.7326/ m13-2275.

\section{Published Version}

doi:10.7326/M13-2275

\section{Permanent link}

http://nrs.harvard.edu/urn-3:HUL.InstRepos:14085946

\section{Terms of Use}

This article was downloaded from Harvard University's DASH repository, and is made available under the terms and conditions applicable to Other Posted Material, as set forth at http:// nrs.harvard.edu/urn-3:HUL.InstRepos:dash.current.terms-of-use\#LAA

\section{Share Your Story}

The Harvard community has made this article openly available.

Please share how this access benefits you. Submit a story.

\section{Accessibility}




\section{Changes in Mortality after Massachusetts' Health Care Reform}

Benjamin D. Sommers, ${ }^{a}$ M.D., Ph.D., Sharon K. Long, ${ }^{b}$ Ph.D., Katherine Baicker, ${ }^{c}$ Ph.D.

Author Affiliations

a - CORRESPONDING AUTHOR

Assistant Professor of Health Policy \& Economics / Assistant Professor of Medicine

Harvard School of Public Health / Brigham \& Women's Hospital

677 Huntington Ave, Room 406

Boston, MA 02115

bsommers@hsph.harvard.edu

Telephone: 617-432-3271

Fax: 617-432-3417

b - Senior Fellow

Health Policy Center

Urban Institute

2100 M Street, NW

Washington, DC 20037

slong@urban.org

c - Professor of Health Economics

Department of Health Policy \& Management

Harvard School of Public Health

677 Huntington Ave, Room 401

Boston, MA 02115

kbaicker@hsph.harvard.edu

Word Count: 3210

Abstract: 280

Version Date: $1 / 23 / 14$ 


\section{ABSTRACT}

Background: Massachusetts' 2006 health reform has been called a model for the Affordable Care Act. The law attained near-universal insurance coverage and increased access to care. Its impact on population health is less clear.

Objective: To determine whether Massachusetts' reform was associated with changes in allcause mortality and mortality from causes amenable to health care.

Design: Comparison of mortality rates before and after reform in Massachusetts versus a control group with similar population demographics and economic conditions.

Setting: Massachusetts' reform created a natural experiment on health insurance expansion. We compared changes in mortality rates for adults in Massachusetts counties from 2001-2005 (prereform) to 2007-2010 (post-reform), versus changes in a propensity-score defined control group of counties in other states.

Participants: Adults ages 20-64 in Massachusetts and control counties.

Outcome Measures: Annual county-level all-cause mortality in sex-age-race specific cells (cells: $n=146,825$ ) from the CDC's Compressed Mortality File. Secondary outcomes were deaths from causes amenable to health care; insurance coverage; access to care; and self-reported health.

Results: Massachusetts' reform was associated with a significant decline in all-cause mortality compared to the control group ( -2.9 percent, $\mathrm{p}=0.003$, or an absolute decline of 8.2 deaths per $100,000)$. Deaths from causes amenable to health care also significantly declined ( -4.5 percent, $\mathrm{p}<0.001)$. Changes were larger in counties with lower household incomes and higher pre-reform uninsured rates. Secondary analyses showed significant gains in coverage, access to care, and self-reported health. The number-needed-to-treat was approximately 830 people gaining health insurance to prevent one death per year.

Limitations: Non-randomized design subject to unmeasured confounders; Massachusetts may not generalize to other states.

Conclusions: Massachusetts' reform was associated with significant declines in all-cause mortality and deaths from causes amenable to health care.

Primary Funding Source: None. 


\section{INTRODUCTION}

Massachusetts passed comprehensive health reform in 2006 with the goal of nearuniversal coverage. The law - which expanded Medicaid, offered subsidized private insurance, and created an individual mandate - was a model for the Affordable Care Act (ACA). ${ }^{1}$ Thus, understanding the Massachusetts law's impact has important policy implications.

Previous research documents that Massachusetts' reform succeeded in expanding health insurance among adults ages 19 to 64 by 3-8 percentage points. ${ }^{1-5}$ Studies also indicate improvements in access to care, ${ }^{6-8}$ self-reported physical and mental health, ${ }^{9}$ use of preventive services, ${ }^{2,10}$ and functional status. ${ }^{1,11}$ However, there has been no evidence on the law's effect on mortality. Previous research of health insurance's impact on mortality is mixed. Some observational studies suggest as much as a $40 \%$ higher risk of death for uninsured versus insured adults, ${ }^{12,13}$ and one analysis of Medicaid expansions to low-income adults detected a $6 \%$ decline in statewide mortality. ${ }^{14}$ Other studies - including two randomized trials of insurance expansion - found little or no mortality impact. ${ }^{15-17}$

This study's objective was to examine the changes in mortality associated with Massachusetts' reform. We hypothesized that the reform reduced mortality, particularly from causes potentially treatable with timely care (such as cardiovascular disease, infections, and cancer), and that larger changes occurred among groups likely to benefit from the law previously uninsured adults and those with higher baseline mortality. 


\section{METHODS}

\section{Study Design}

Our study used a quasi-experimental pre-post design with a control group, comparing average mortality in Massachusetts before and after reform to mortality changes over the same period for similar populations in states without reforms (also known as a "differences-indifferences" analysis ${ }^{18}$ ). Our preferred specification employed propensity-score methods to create a control group of counties in non-reform states that best matched the distribution of prereform characteristics in Massachusetts counties. ${ }^{19,20}$

The Massachusetts law had several components: a Medicaid expansion starting in July 2006 for adults; subsidized private plans for adults under $100 \%$ of the federal poverty level (FPL) in October 2006; and expanded coverage subsidies for adults up to $300 \%$ of FPL in January 2007. It included an individual mandate effective for the 2007 tax year, as well as "minimum creditable coverage" insurance standards. ${ }^{21}$ We defined the post-reform period as 2007-2010, with 2006 omitted as a transitional year (though we included 2006 in sensitivity analyses). Our pre-reform period was 2001-2005.

\section{Data}

Our data came primarily from the Centers for Disease Control and Prevention (CDC)'s Compressed Mortality File, which provides county-specific annual mortality rates stratified by

age, sex, and race. ${ }^{22}$ For confidentiality, the publicly-available dataset suppresses death counts for cells with fewer than 10 deaths; we obtained access to the non-suppressed dataset under agreement with the CDC. Our sample contained adults ages 20-64, the group most directly targeted by the reform (with 19 year-olds excluded because 15-19 year-olds are grouped together 
in the dataset). In addition to age, sex, and race, our estimates adjusted for year-specific countylevel poverty rates, median income, unemployment, and Latino percentage of the population, all from the Area Resource File (ARF). ${ }^{23}$ Subgroup analyses used pre-reform county-level uninsured rates from the Census Bureau's 2005 Small Area Health Insurance Estimates. ${ }^{24}$

We also analyzed measures of coverage, health care access, and self-reported health status from two nationally-representative household surveys: CDC's Behavioral Risk Factor Surveillance System (BRFSS) and the Census Bureau's Current Population Survey (CPS).

These datasets have been used previously to examine the impact of the Massachusetts reform on coverage and access $;^{2-4,8,9,25}$ we present independent estimates using methods analogous to our mortality analysis to provide additional context for our results. For these data sources, we were able to include 19 year-olds, so the sample contains all non-elderly adults 19-64.

This project used pre-existing deidentified data and was deemed exempt from review by the Harvard Institutional Review Board. The project received no external funding.

\section{Outcome Measures}

Our primary outcome was all-cause mortality. Our secondary outcome was mortality amenable to health care, adapted from previous research, to focus on deaths related to conditions that are more likely to be preventable or treatable with timely care ${ }^{26-29}$ including deaths due to heart disease, stroke, cancer, infections and other conditions. ${ }^{30}$ Appendix Table 1 lists the ICD10 codes in this definition and a more restrictive alternate definition tested in a sensitivity analysis.

Additional outcomes were health insurance from the CPS, and self-reported health (excellent/very good versus good/fair/poor) and access-to-care measures (cost-related delays in 
care, lacking a usual source of care, and absence of a preventive visit in the past year) from the BRFSS.

\section{Analysis}

Annual age-sex-race-specific county-level death counts were the unit of observation for the mortality analysis. Table 1 describes the analytic sample, which contains information on the number of counties, states, age-sex-race-specific county-level cells, and population per year.

Our regression models estimated the average annual pre-post change in mortality for agesex-race-specific cells in Massachusetts counties relative to comparison counties in non-reform states. Given that our dataset presents deaths as count data within each cell, multivariate regression analyses fitted a generalized linear model (GLM), using a negative binomial distribution and log-link, with cell population as the exposure variable. Analyses adjusted for race, sex, age, state, year, and county-year-specific economic factors listed above (see Appendix for details).

Our study contained five years of pre-reform data (2001-2005) and four years of postreform data (2007-2010), and our model estimated the change in level of mortality pre- versus post-reform. ${ }^{31}$ Robust standard errors were clustered at the state level to account for serial autocorrelation and for the state-level nature of the policy intervention, ${ }^{18}$ as is standard in population-based policy analyses..$^{14,32-37}$ Sensitivity analyses included pooling annual data into pre-reform and post-reform periods to remove potential autocorrelation, an interrupted timeseries model, adding 2006 (the implementation year) to our post-reform data, and county-level clustering of standard errors. We also tested a linear model using death rate per 100,000 adults 
as the outcome, to provide simple estimates of absolute change and results comparable to prior research. ${ }^{14}$ Cells were weighted by population size to yield population-representative estimates. Secondary analyses used individual-level information from the BRFSS and CPS on coverage, access, and health status, and adjusted for age, sex, race/ethnicity, employment, household income, year, and state. For these binary outcomes, we used a generalized linear model with a logit link, with predicted probabilities used to describe the magnitude of absolute changes. ${ }^{38}$

\section{Selection of Control Group}

For the mortality analysis, we used propensity scores to define a control group of counties in non-reform states that were most similar to Massachusetts counties prior to reform. We estimated propensity scores with a population-weighted logistic regression model using age distribution, sex, race/ethnicity, poverty rate, median income, unemployment, uninsured rate, and baseline annual mortality as predictors (Appendix Table 2). The quartile of counties with the highest propensity scores - indicating the closest match to the overall population of Massachusetts' 14 counties - were used as the control group in the mortality analysis. This approach yielded excellent balance on key features between Massachusetts and our control group (Table 2) and provided adequate sample sizes for subgroup analyses. We also tested a more traditional propensity score regression adjustment method and a 2:1 nearest-neighbor propensity score matching approach, which yielded similar overall results (see Appendix for details).

Identifying a control group with similar trends in mortality absent Massachusetts' reform is the key to our approach. ${ }^{20}$ We tested for differences in the pre-reform mortality trends for 2001-2006 between Massachusetts and the control group, using both linear and quadratic time 
trends interacted with an indicator variable for Massachusetts. We repeated this test for the full U.S. population.

For the analysis of coverage, access, and self-reported health in the CPS and BRFSS, we compared Massachusetts to other New England states (Maine, Vermont, New Hampshire, Rhode Island, and Connecticut) before and after reform. These datasets do not contain the county-level detail needed for our propensity score method, so we follow previous research in using this control group. ${ }^{2,3,11}$

\section{Subgroup Analyses}

We conducted pre-specified subgroup analyses to test for heterogeneous mortality changes and impact on disparities. We examined 20-34 versus 35-64 year-olds; white nonLatinos versus non-whites and Latinos; residents of low- versus high-income counties (based on Massachusetts' median household income); and residents of counties with low versus high adult uninsured rates (based on Massachusetts' pre-reform median county uninsured rates). In each analysis, we specified an interaction term between Massachusetts' reform and the variable in question, to test whether there were significantly different impacts across subgroups.

Finally, we used elderly adults (65 and older) as an additional control group. This approach subtracts out any secular trend for elderly adults in Massachusetts from the estimated mortality change for non-elderly adults (see Appendix for details). Netting out the mortality changes in this group is a conservative approach: while Massachusetts' reform did not directly affect coverage for most elderly adults, it did expand insurance to the few who do not meet lifetime earnings requirement for Medicare. ${ }^{2,39}$ It may thus have had some impact on health in 
this age group, but one would expect such effects to be much weaker than the impact on the targeted population of non-elderly adults.

\section{RESULTS}

\section{Sample}

Table 2 presents descriptive statistics and baseline mortality for counties in Massachusetts, our control group, and all U.S. counties outside Massachusetts. Massachusetts had significantly fewer minorities, more women, lower poverty and uninsured rates, and lower baseline mortality than the rest of the U.S. However, there were no statistically significant differences for these outcomes between Massachusetts and the control group, indicating excellent balance from the propensity score approach.

Examination of pre-reform mortality trends further supports the use of control group (Appendix Table 3). We found no evidence of divergence between Massachusetts and the control group in either linear or quadratic models ( $p>0.10)$. In contrast, Massachusetts' mortality trend diverged from the rest of the U.S. before $2006(\mathrm{p}<0.001)$.

\section{Changes in Mortality}

Figure 1 shows unadjusted annual mortality for non-elderly adults in Massachusetts and the control group from 2001-2010. All-cause mortality in the two groups followed a similar pattern until the reform law's implementation in 2006-2007, after which mortality in Massachusetts began to decline relative to the control group. Health-care amenable mortality followed a similar pattern, while trends for other causes of death showed minimal changes within Massachusetts and the control group. 
Table 3 presents regression estimates for changes in mortality associated with Massachusetts' reform. In our primary specification, adjusted all-cause mortality declined in Massachusetts after reform by $2.9 \%(\mathrm{p}=0.003)$, compared to the control group. Mortality amenable to health care declined by $4.5 \%(\mathrm{p}<0.001)$. An alternate definition of health-care amenable mortality ${ }^{28}$ produced a slightly larger relative reduction $(-5.5 \%, \mathrm{p}=0.002)$, and deaths from non-amenable causes showed no significant decline $(-2.0 \%, \mathrm{p}=0.26)$ (Appendix Table 1).

Numerous sensitivity analyses - including using propensity-score regression adjustment or 2:1 matching approaches, county-level clustered standard errors, or a linear model with the death rate as the outcome - produced similar results (Appendix Table 4). The relative decline of $2.9 \%$ in all-cause mortality, paired with baseline mortality in Massachusetts of 283 per 100,000, implies an absolute mortality reduction of -8.2 per 100,000 , similar to the linear model estimate of -9.3 per $100,000(\mathrm{p}=0.014)$ reported in the Appendix.

\section{Mortality Changes Among Subgroups}

Table 4 presents subgroup analyses. Relative mortality reductions in Massachusetts compared to the control group were significant for whites and non-whites, 20-34 and 35-64 yearolds, and residents of counties with lower incomes and higher baseline uninsured rates. While relative mortality changes were larger for Latinos and non-whites $(-4.6 \%, \mathrm{p}<0.001)$ than for whites $(-2.4 \%, \mathrm{p}=0.001)$, the between-group difference in these estimates was not significant $(\mathrm{p}=0.062)$

Appendix Figure 1 shows unadjusted mortality trends for elderly adults, with no apparent divergence between Massachusetts and the control group before or after reform. A model using elderly adults as an additional within-state control group (Appendix Table 5) showed a -3.3\% 
change in all-cause mortality $(\mathrm{p}=0.066)$ for non-elderly adults and $+0.1 \%$ for elderly adults $(\mathrm{p}=0.93)$ in Massachusetts after reform, and a $-4.9 \%$ change in health-care amenable mortality $(\mathrm{p}<0.001)$ for non-elderly adults and $\mathrm{a}+0.2 \%$ change for elderly adults $(\mathrm{p}=0.90)$.

\section{Coverage, Access to Care, and Health}

Table 5 shows changes in coverage, access to care, and self-reported health. Compared to other New England states, Massachusetts' reform was associated with significant reductions in the uninsured rate (-6.8 percentage-point change in predicted probability, a 57\% relative decline from baseline), cost-related delays in care (-2.0 percentage points, $22 \%$ relative decline), lacking a usual source of care (-1.9 percentage points, $13 \%$ relative decline), having no preventive visit in the last year (-4.0 percentage points, $13 \%$ relative decline), and reporting good, fair or poor health (-1.8 percentage points, $5 \%$ relative decline), all changes $p<0.01$. Results were nearly identical with linear probability models or without state-clustering of standard errors (Appendix Table 6).

\section{Estimated Mortality Effect}

To assess the plausibility of our estimated mortality decline, we compared it with the coverage gains we detected (Appendix Table 7). In absolute terms, we found a 0.082 percentage-point decline in mortality $(8.2$ per 100,000$)$ in the setting of a 6.8 percentage-point coverage gain, which implies that for approximately every 830 individuals who gained insurance, there was one fewer death per year. 


\section{DISCUSSION}

Massachusetts' 2006 health reform was associated with significant declines in all-cause mortality over 4 years of follow-up, relative to a control group of similar counties in states without reform. Declines were concentrated in causes of death more likely amenable to health care and in populations most likely to benefit from expanded access, particularly residents of counties with lower incomes and higher pre-reform uninsured rates.

Compared to the control group, overall mortality in Massachusetts declined by $2.9 \%$. This relative decline in mortality is smaller than the $6.1 \%$ mortality decline associated with several states' Medicaid expansions, ${ }^{14}$ consistent with the fact that Massachusetts began its expansion from a much higher baseline rate of insurance coverage. However, two recent experimental studies of insurance have not shown a mortality benefit of insurance, ${ }^{16,17}$ nor statistically significant changes in blood pressure or glycated hemoglobin, ${ }^{40}$ though both found major gains in self-reported health and access to recommended care. The latter studies have the advantages of a randomized design and individual-level data, but involve much smaller sample sizes (e.g. 916 gaining coverage in one study, ${ }^{17}$ roughly 10,000 newly-insured in another, ${ }^{40}$

versus approximately 270,000 adults gaining coverage in our study) and shorter follow-up ${ }^{16,40}$ than is possible using state-wide population data, giving our study far greater statistical power for small absolute changes such as those detected here.

How does insurance expansion reduce population mortality? Our secondary outcomes trace out a plausible causal pathway: eligibility leads to increased coverage, coverage leads to better access and more utilization of clinical services including office visits, with resulting gains in self-reported health status (a strong predictor of mortality ${ }^{41,42}$ ). This potential pathway of coverage leading to health gains via access to clinicians and high-quality care is consistent with 
Eisenberg and Power's seminal 2000 paper, which outlines a framework for understanding challenges to improving care for patients within the U.S. health care system. ${ }^{43}$

Our results are consistent with the bulk of previous research on Massachusetts' reform, demonstrating gains in coverage, access to care, and self-reported health among Massachusetts residents post-reform. ${ }^{1,2,8,10,11}$ Mortality reductions were concentrated in those conditions most likely amenable to health care, such as cancer (which can sometimes be prevented with earlier screening and/or treated more successfully with early detection), infections (treatable with early detection, and preventable or less likely to be fatal with better chronic disease management), and cardiovascular disease (treatable acutely with early detection, and partially preventable with risk factor modification). This is consistent with research demonstrating a decline in potentially avoidable hospitalizations after Massachusetts' reform ${ }^{2}$ and other insurance expansions. ${ }^{44}$ While research on breast cancer did not find a significant effect of Massachusetts' reform, ${ }^{25}$ our use of a more comprehensive health outcome may have given us greater power to detect changes than analysis of a single diagnosis.

Our "number needed to treat" was 830 adults gaining insurance to prevent one death per year. This estimated coverage-to-mortality effect would be consistent with a $30 \%$ relative reduction in individual-level mortality for those gaining insurance (compared to an estimated $25 \%$ relative reduction in mortality from insurance cited by the Institute of Medicine, ${ }^{13}$ and the $40 \%$ relative reduction found by Wilper et al. ${ }^{12}$ ), if overall baseline mortality for these uninsured individuals were 400 per 100,000 (Appendix Table 7). This baseline mortality rate would be roughly 1.5 times that of our overall sample, consistent with prior research on elevated mortality risks for the uninsured. ${ }^{12,15}$ In addition, research suggests that insurance expansions disproportionately enroll individuals in worse health, ${ }^{14,45}$ and components of the Massachusetts 
expansion preferentially targeted adults with disabilities or HIV/AIDS. ${ }^{21}$ These illustrative calculations assume that mortality reductions occurred only for those obtaining insurance under reform, which may be conservative, since the law also expanded benefits (including preventive care and prescription drugs) for many who already had insurance.

Reductions in mortality were largest in Massachusetts counties with lower incomes and lower pre-reform insurance coverage - areas likely to have experienced the greatest increase in access to care under reform. Mortality reductions were nearly twice as large for minorities as for whites, though this between-group difference was not statistically significant. These results provide useful additional information compared to previous research suggesting that racial/ethnic disparities in coverage and access may not have narrowed after Massachusetts' reform., ${ }^{3,4}$

Our analysis has several limitations. First, we do not have individual-level insurance information and thus cannot directly link mortality changes to those gaining insurance coverage. Second, defining mortality from causes "amenable to health care" is somewhat subjective. We built on methods used in prior research ${ }^{27-29}$ and tested two definitions that provided similar results. Future research distinguishing between treatable and curable conditions would also be worthwhile.

Most importantly, our quasi-experimental approach cannot definitively demonstrate a causal relationship underlying the association between Massachusetts' reform and the state's declining mortality relative to other states. It is possible that the post-reform reduction in mortality in Massachusetts was due to other factors that differentially affected Massachusetts, such as the recession. However, our analysis controlled for several distinct time- and countyspecific economic measures. We also found no evidence of a similar decline in mortality among elderly adults in Massachusetts that would suggest a secular trend. While we cannot rule out 
unmeasured confounders, it is challenging to identify factors other than health reform that might have produced this pattern of results: a declining mortality rate in Massachusetts since 2007 not present in similar counties elsewhere in the country, primarily for health-care amenable causes in adults ages 20-64 (but not elderly adults), concentrated among poor and uninsured areas, and not explained by changes in poverty or unemployment rates.

In conclusion, we find a significant reduction in mortality among non-elderly adults in Massachusetts since its 2006 reform, relative to a control group of similar counties in states without such reforms. Though this analysis is unable to demonstrate causality, the results offer suggestive evidence that the ACA - modeled after the Massachusetts law - may impact not only coverage and access, but also mortality. However, it is critical to note the many dimensions along which Massachusetts differs from the rest of the nation, with lower mortality, higher income and baseline insurance coverage rates, fewer minorities, and the most physicians per capita in the country. ${ }^{46}$ The extent to which our results generalize to the U.S. as a whole is therefore unclear, underscoring the need to monitor closely across all states the ACA's impact on coverage, access, and population health. 


\section{Reprint Requests}

Requests for reprints should be sent to:

Benjamin D. Sommers

Harvard School of Public Health

677 Huntington Ave, Room 406

Boston, MA 02115

bsommers@hsph.harvard.edu

\section{Acknowledgments}

We are grateful to James Ware at the Harvard School of Public Health for thoughtful advice on our statistical analysis. We would also like to thank Jacob Robbins and Sarah Gordon, Research Assistants at the Harvard School of Public Health, for their work on this project, and Katherine Hempstead at the Robert Wood Johnson Foundation for helpful suggestions related to healthcare amenable mortality. Drs. Sommers and Long reported no financial conflicts of interest. Dr. Baicker reported a relationship with Eli Lilly. Dr. Sommers is currently serving as an advisor in the Office of the Assistant Secretary for Planning and Evaluation, at the U.S. Department of Health and Human Services (HHS). However, this paper was written in Dr. Sommers' capacity as a Harvard employee, and this paper does not represent the views of HHS. Previous versions of this study were presented at the national conferences of the Society of General Internal Medicine and AcademyHealth in 2013. 


\section{References}

1. Long SK, Stockley K, Dahlen H. Massachusetts health reforms: uninsurance remains low, self-reported health status improves as state prepares to tackle costs. Health Aff (Millwood) 2012;31:444-51.

2. Kolstad JT, Kowalski AE. The Impact of Health Care Reform on Hospital and Preventive Care: Evidence from Massachusetts. Journal of Public Economics 2012;96:909-29.

3. Zhu J, Brawarsky P, Lipsitz S, Huskamp H, Haas JS. Massachusetts health reform and disparities in coverage, access and health status. J Gen Intern Med 2010;25:1356-62.

4. Clark CR, Soukup J, Govindarajulu U, Riden HE, Tovar DA, Johnson PA. Lack of access due to costs remains a problem for some in Massachusetts despite the state's health reforms. Health Aff (Millwood) 2011;30:247-55.

5. Key Indicators: Quarterly Enrollment Update. Boston, MA: Massachusetts Division of Health Care Finance and Policy; 2011.

6. Long SK. On the road to universal coverage: impacts of reform in massachusetts at one year. Health Aff (Millwood) 2008;27:w270-84.

7. Long SK, Masi PB. Access and affordability: an update on health reform in Massachusetts, fall 2008. Health Aff (Millwood) 2009;28:w578-87.

8. Pande AH, Ross-Degnan D, Zaslavsky AM, Salomon JA. Effects of healthcare reforms on coverage, access, and disparities: quasi-experimental analysis of evidence from Massachusetts. Am J Prev Med 2011;41:1-8.

9. PJ VDW, Zaslavsky AM, Ayanian JZ. Improvements in health status after massachusetts health care reform. Milbank Q 2013;91:663-89.

10. Miller S. The effect of the Massachusetts reform on health care utilization. Inquiry 2012;49:317-26.

11. Courtemanche CJ, Zapata D. Does universal coverage improve health? The Massachusetts experience: National Bureau of Economic Research; 2012.

12. Wilper AP, Woolhandler S, Lasser KE, McCormick D, Bor DH, Himmelstein DU. Health insurance and mortality in US adults. Am J Public Health 2009;99:2289-95.

13. Care without coverage: too little, too late. Washington, D.C.: Institute of Medicine; 2002. 14. Sommers BD, Baicker K, Epstein AM. Mortality and Access to Care among Adults after State Medicaid Expansions. N Engl J Med 2012.

15. Kronick R. Health insurance coverage and mortality revisited. Health Serv Res 2009;44:1211-31.

16. Finkelstein A, Taubman S, Wright BJ, et al. The Oregon health insurance experiment: evidence from the first year. Cambridge, MA: National Bureau of Economic Research; 2011.

17. Weathers RR, 2nd, Stegman M. The effect of expanding access to health insurance on the health and mortality of Social Security Disability Insurance beneficiaries. J Health Econ 2012;31:863-75.

18. Bertrand M, Duflo E, Mullainathan S. How Much Should We Trust Differences-inDifferences Estimates? Quarterly Journal of Economics 2004;119:249-75.

19. Dehejia RH, Wahba S. Propensity-Score Matching Methods for Nonexperimental Causal Studies. Review of Economics and Statistics 2002;84:151-61.

20. Abadie A, Diamond A, Hainmueller J. Comparative Politics and the Synthetic Control Method. Cambridge, MA: Harvard Kennedy School; 2012. 
21. McDonough JE, Rosman B, Phelps F, Shannon M. The third wave of Massachusetts health care access reform. Health Aff (Millwood) 2006;25:w420-31.

22. National Center for Health Statistics. Compressed Mortality File, 1999-2010 (machine readable data file and documentation, CD ROM Series 20, No. 2P) as compiled from data provided by the 57 vital statistics jurisdictions through the Vital Statistics Cooperative Program. Hyattsville, Maryland. 2012.

23. Area Resource File (ARF). 2011-2012. US Department of Health and Human Services, Health Resources and Services Administration, Bureau of Health Professions, Rockville, MD.

24. US Census Bureau, Small Area Health Insurance Estimates Program, 2005. Accessed 3 October 2012 at $<$ http://www.census.gov/did/www/sahie/data/index.html $>$

25. Keating NL, Kouri EM, He Y, West DW, Winer EP. Effect of Massachusetts health insurance reform on mammography use and breast cancer stage at diagnosis. Cancer

2013;119:250-8.

26. Charlton JR, Velez R. Some international comparisons of mortality amenable to medical intervention. Br Med J (Clin Res Ed) 1986;292:295-301.

27. Mackenbach JP, Bouvier-Colle MH, Jougla E. "Avoidable" mortality and health services: a review of aggregate data studies. J Epidemiol Community Health 1990;44:106-11.

28. Nolte E, McKee M. Measuring the health of nations: analysis of mortality amenable to health care. Bmj 2003;327:1129.

29. Nolte E, McKee CM. Measuring the health of nations: updating an earlier analysis. Health Aff (Millwood) 2008;27:58-71.

30. Nolte E, McKee M. Variations in amenable mortality--trends in 16 high-income nations. Health Policy 2011;103:47-52.

31. Singer JD, Willett JB. Applied Longitudinal Data Analysis: Modeling Change and Event Occurrence. USA: Oxford University Press; 2003.

32. Afendulis CC, He Y, Zaslavsky AM, Chernew ME. The impact of Medicare Part D on hospitalization rates. Health Serv Res 2011;46:1022-38.

33. Bendavid E, Bhattacharya J. The President's Emergency Plan for AIDS Relief in Africa: an evaluation of outcomes. Ann Intern Med 2009;150:688-95.

34. Cooper AL, Trivedi AN. Fitness memberships and favorable selection in Medicare Advantage plans. N Engl J Med 2012;366:150-7.

35. Cotet AM, Benjamin DK. Medical Regulation and Health Outcomes: The Effect of the Physician Examination Requirement. Health Econ 2012.

36. Lien DS, Evans WN. Estimating the Impact of Large Cigarette Tax Hikes: The Case of Maternal Smoking and Infant Birth Weight. Journal of Human Resources 2005;40:373-92.

37. Besley T, Burgess R. Can Labor Regulation Hinder Economic Performance? Evidence from India. Quarterly Journal of Economics 2004;119:91-134.

38. Karaca-Mandic P, Norton EC, Dowd B. Interaction terms in nonlinear models. Health Serv Res 2012;47:255-74.

39. Gray BH, Scheinmann R, Rosenfeld P, Finkelstein R. Aging without Medicare? Evidence from New York City. Inquiry 2006;43:211-21.

40. Baicker K, Taubman S, Allen H, et al. The Oregon Experiment - Effects of Medicaid on Clinical Outcomes. N Engl J Med 2013;368:1713-22.

41. Miilunpalo S, Vuori I, Oja P, Pasanen M, Urponen H. Self-rated health status as a health measure: the predictive value of self-reported health status on the use of physician services and on mortality in the working-age population. J Clin Epidemiol 1997;50:517-28. 
42. DeSalvo KB, Bloser N, Reynolds K, He J, Muntner P. Mortality prediction with a single general self-rated health question. A meta-analysis. J Gen Intern Med 2006;21:267-75.

43. Eisenberg JM, Power EJ. Transforming insurance coverage into quality health care: voltage drops from potential to delivered quality. Jama 2000;284:2100-7.

44. DeLeire T, Dague L, Leininger L, Voskuil K, Friedsam D. Wisconsin Experience Indicates that Expanding Public Insurance to Low-Income Childless Adults Has Health Care Impacts. Health Aff (Millwood) 2013;32.

45. Sommers BD, Kenney GM, Epstein AM. New evidence on the affordable care act: coverage impacts of early medicaid expansions. Health Aff (Millwood) 2014;33:78-87.

46. U.S. Census Bureau. "State Rankings - Stastical Abstract of the United States." (2012). Available at: <http://www.census.gov/compendia/statab/2012/ranks/rank18.html $>$, accessed 12 November 2012. 
Table 1: Analytic Sample

\begin{tabular}{|l|l|}
\hline Variable & Value \\
\hline Counties & \\
\hline Massachusetts Counties & 14 \\
\hline Control Group Counties & 513 \\
\hline United States (non-Massachusetts) & 3127 \\
\hline & \\
\hline States (including District of Columbia) & \\
\hline Massachusetts & 1 \\
\hline Control Group States & 46 \\
\hline United States (non-Massachusetts) & 50 \\
\hline & \\
\hline County-Specific Age-Sex-Race Cells & \\
\hline Massachusetts Cells & 3,985 \\
\hline Control Group Cells & 142,840 \\
\hline United States (non-Massachusetts) & 836,413 \\
\hline & \\
\hline Population Per Year, Ages 20-64 & \\
\hline Massachusetts & $3,900,000$ \\
\hline Control Group & $44,300,000$ \\
\hline United States (non-Massachusetts) & $173,400,000$ \\
\hline
\end{tabular}


Table 2: Summary Statistics for Study Sample, Pre-Reform Period

\begin{tabular}{|c|c|c|c|c|c|}
\hline County-Level Characteristic & Massachusetts & Control Group & $\begin{array}{c}\text { P value, } \\
\text { Massachusetts } \\
\text { vs. Control } \\
\text { Group }\end{array}$ & $\begin{array}{l}\text { Rest of } \\
\text { United } \\
\text { States }\end{array}$ & $\begin{array}{c}\text { P value, } \\
\text { Massachusetts } \\
\text { vs. Rest of } \\
\text { United States }\end{array}$ \\
\hline \multicolumn{6}{|l|}{ Covariates } \\
\hline Age $20-34$ & $33.2 \%$ & $33.1 \%$ & 0.95 & $34.5 \%$ & 0.46 \\
\hline Age $35-44$ & $26.3 \%$ & $25.9 \%$ & 0.51 & $25.3 \%$ & 0.090 \\
\hline Age $45-54$ & $24.0 \%$ & $24.3 \%$ & 0.69 & $23.7 \%$ & 0.68 \\
\hline Age 55-64 & $16.5 \%$ & $16.7 \%$ & 0.79 & $16.4 \%$ & 0.95 \\
\hline Male & $48.9 \%$ & $49.1 \%$ & 0.13 & $49.6 \%$ & $<0.001$ \\
\hline White & $87.4 \%$ & $85.0 \%$ & 0.28 & $81.0 \%$ & 0.003 \\
\hline Black & $7.0 \%$ & $9.0 \%$ & 0.26 & $12.8 \%$ & $<0.001$ \\
\hline Other Race & $5.6 \%$ & $6.0 \%$ & 0.62 & $6.2 \%$ & 0.46 \\
\hline Latino Ethnicity & $7.6 \%$ & $7.9 \%$ & 0.86 & $14.0 \%$ & $<0.001$ \\
\hline Poverty Rate & $9.6 \%$ & $10.2 \%$ & 0.55 & $12.7 \%$ & 0.002 \\
\hline Median Household Income $\dagger$ & $\$ 62,271$ & $\$ 59,124$ & 0.30 & $\$ 52,481$ & 0.001 \\
\hline Unemployment Rate & $5.0 \%$ & $5.1 \%$ & 0.62 & $5.4 \%$ & 0.058 \\
\hline Uninsured Rate & $13.6 \%$ & $14.5 \%$ & 0.18 & $19.8 \%$ & $<0.001$ \\
\hline \multicolumn{6}{|l|}{ Outcomes } \\
\hline $\begin{array}{l}\text { All-Cause Mortality (deaths per } \\
100,000)\end{array}$ & 283 & 297 & 0.26 & 341 & $<0.001$ \\
\hline $\begin{array}{l}\text { Mortality Amenable to Health } \\
\text { Care (deaths per } 100,000)\end{array}$ & 185 & 197 & 0.11 & 221 & $<0.001$ \\
\hline
\end{tabular}

Notes:

$\dagger$ Median income was inflation-adjusted to 2010 dollars. 
Table 3: Mortality Before and After Massachusetts' Health Reform Among Adults 20-64 (2001-2010)

\begin{tabular}{|c|c|c|c|c|c|c|c|c|}
\hline \multirow[t]{2}{*}{ OUTCOME } & \multicolumn{2}{|c|}{$\begin{array}{c}\text { Unadjusted } \\
\text { Mortality, per } \\
\mathbf{1 0 0 , 0 0 0}\end{array}$} & \multicolumn{3}{|c|}{$\begin{array}{l}\text { Unadjusted Relative Change } \\
\text { (percent) }\end{array}$} & \multicolumn{3}{|c|}{$\begin{array}{c}\text { Adjusted Relative Change } \\
\text { (percent) }\end{array}$} \\
\hline & $\begin{array}{c}\text { Pre- } \\
\text { Reform }\end{array}$ & $\begin{array}{l}\text { Post- } \\
\text { Reform }\end{array}$ & $\begin{array}{l}\text { Difference in } \\
\text { Change, } \\
\text { Massachusetts } \\
\text { vs. Control } \\
\text { Group } \\
\end{array}$ & $95 \%$ CI & $\begin{array}{c}P \\
\text { value }\end{array}$ & $\begin{array}{l}\text { Difference in } \\
\text { Change, } \\
\text { Massachusetts } \\
\text { vs. Control } \\
\text { Group } \\
\end{array}$ & $95 \%$ CI & $\begin{array}{c}P \\
\text { value }\end{array}$ \\
\hline \multicolumn{9}{|l|}{$\begin{array}{l}\text { All-Cause } \\
\text { Mortality }\end{array}$} \\
\hline Massachusetts & 283 & 274 & \multirow{2}{*}{-4.2} & \multirow{2}{*}{$-8.0,-0.4$} & \multirow{2}{*}{0.032} & \multirow{2}{*}{-2.9} & \multirow{2}{*}{$-4.8,-1.0$} & \multirow{2}{*}{0.003} \\
\hline Control Group & 297 & 299 & & & & & & \\
\hline \multicolumn{9}{|l|}{$\begin{array}{l}\text { Health Care } \\
\text { Amenable } \\
\text { Mortality } \\
\end{array}$} \\
\hline Massachusetts & 185 & 175 & \multirow{2}{*}{-4.3} & \multirow{2}{*}{$-7.2,-1.5$} & \multirow{2}{*}{0.003} & \multirow{2}{*}{-4.5} & \multirow{2}{*}{$-6.2,-2.7$} & \multirow{2}{*}{$<0.001$} \\
\hline Control Group & 197 & 195 & & & & & & \\
\hline
\end{tabular}

Notes: Relative changes estimated using negative binomial generalized linear models with log-link. Adjusted model controlled for population age, sex, race, and ethnicity distribution, poverty rate, median income, unemployment rate, and state of residence. 
Table 4: Subgroup Analyses of All-Cause Mortality Changes After Massachusetts' Health Reform Among Adults 20-64 (2001-2010)

\begin{tabular}{|c|c|c|c|c|c|c|}
\hline SUBGROUP & $\begin{array}{c}\text { Unadjusted } \\
\text { Mortality in } \\
\text { Massachusetts } \\
\text { Prior to } \\
\text { Reform, per } \\
\mathbf{1 0 0 , 0 0 0}\end{array}$ & $\begin{array}{c}\text { Adjusted } \\
\text { Relative } \\
\text { Change, } \\
\text { Massachusetts } \\
\text { vs. Control } \\
\text { Group } \\
\text { (percent) }\end{array}$ & $95 \% \mathrm{CI}$ & $\begin{array}{l}\text { P value } \\
\text { for } \\
\text { subgroup }\end{array}$ & $\begin{array}{c}\text { P value } \\
\text { for } \\
\text { between- } \\
\text { group } \\
\text { difference }\end{array}$ & $\begin{array}{c}\text { Absolute } \\
\text { Change in } \\
\text { Predicted } \\
\text { Mortality, } \\
\text { per 100,000 }\end{array}$ \\
\hline Full Sample & 283 & -2.9 & $-4.8,-1.0$ & 0.003 & -- & -8.2 \\
\hline $\begin{array}{l}\text { White Non- } \\
\text { Latino } \\
\text { Latino or Non- } \\
\text { White } \S \\
\end{array}$ & $\begin{array}{l}295 \\
231\end{array}$ & $\begin{array}{l}-2.4 \\
-4.6\end{array}$ & $\begin{array}{l}-3.8,-1.0 \\
-6.3,-2.8 \\
\end{array}$ & $\begin{array}{l}0.001 \\
<0.001\end{array}$ & 0.062 & $\begin{array}{c}-7.1 \\
-10.6\end{array}$ \\
\hline $\begin{array}{l}\text { Ages } 20-34 \\
\text { Ages } 35-64\end{array}$ & $\begin{array}{c}77 \\
386 \\
\end{array}$ & $\begin{array}{l}-3.6 \\
-2.2 \\
\end{array}$ & $\begin{array}{l}-6.9,-0.4 \\
-3.8,-0.6 \\
\end{array}$ & $\begin{array}{l}0.030 \\
0.008 \\
\end{array}$ & 0.38 & $\begin{array}{l}-2.8 \\
-8.5 \\
\end{array}$ \\
\hline $\begin{array}{l}\text { Low-Income } \\
\text { County } \\
\text { High-Income } \\
\text { County } \\
\end{array}$ & 312 & $\begin{array}{l}-3.0 \\
-1.8\end{array}$ & $\begin{array}{l}-4.6,-1.3 \\
-4.0,0.5\end{array}$ & $\begin{array}{l}<0.001 \\
0.120\end{array}$ & 0.33 & $\begin{array}{l}-9.4 \\
-4.6\end{array}$ \\
\hline $\begin{array}{l}\text { Low-Uninsured } \\
\text { County } \\
\text { High-Uninsured } \\
\text { County }\end{array}$ & 295 & -1.7 & $\begin{array}{l}-3.8,0.4 \\
-6.0,-0.6\end{array}$ & $\begin{array}{l}0.118 \\
0.015\end{array}$ & 0.41 & $\begin{array}{l}-5.0 \\
-9.0\end{array}$ \\
\hline
\end{tabular}

Notes: Relative changes estimated using negative binomial generalized linear models with log-link. Adjusted model controlled for population age, sex, race, and ethnicity distribution, poverty rate, median income, unemployment rate, and state of residence. Absolute change calculated using estimated relative change multiplied by baseline subgroupspecific mortality for Massachusetts.

$\S$ While unadjusted mortality is higher for White Non-Latinos than for Latinos or Non-Whites, this is primarily due to the different age distributions of the groups. After adjustment for age by standardizing to the white age distribution, baseline mortality for Latinos or Non-Whites is significantly higher $(312 / 100,000)$ than mortality for White Non-Latinos $(295 / 100,000)$. This model omits from the sample any deaths with "unknown" ethnicity, since the dataset has no corresponding population denominator for that group necessary to calculate a death rate. 


\section{Table 5: Changes in Coverage, Access to Care, and Self-Reported Health After Massachusetts' Health Reform Among Adults 19-64 (2001-2010)}

\begin{tabular}{|c|c|c|c|c|c|c|}
\hline OUTCOME & $\begin{array}{c}\text { Unadjusted } \\
\text { Population Mean } \\
\text { in Massachusetts } \\
\text { Pre-Reform } \\
\text { (percent) }\end{array}$ & $\begin{array}{l}\text { Adjusted Odds } \\
\text { Ratio, Post- } \\
\text { Massachusetts } \\
\text { Health Reform }\end{array}$ & $95 \%$ CI & $P$ value & $\begin{array}{c}\text { Absolute } \\
\text { Change in } \\
\text { Predicted } \\
\text { Probability } \\
\text { (percentage } \\
\text { points) }\end{array}$ & $\mathbf{N}$ \\
\hline Uninsured & 11.9 & 0.43 & $0.41,0.45$ & $<0.001$ & -6.8 & 99,661 \\
\hline $\begin{array}{l}\text { Delayed Care Due } \\
\text { to Cost in Past } \\
\text { Year }\end{array}$ & 9.0 & 0.78 & $0.70,0.86$ & $<0.001$ & -2.0 & 215,365 \\
\hline $\begin{array}{l}\text { No Usual Source } \\
\text { of Care }\end{array}$ & 14.7 & 0.84 & $0.78,0.89$ & $<0.001$ & -1.9 & 262,761 \\
\hline $\begin{array}{l}\text { No Preventive } \\
\text { Doctor's Visit in } \\
\text { Past Year }\end{array}$ & 30.5 & 0.82 & $0.79,0.85$ & $<0.001$ & -4.0 & 166,642 \\
\hline $\begin{array}{l}\text { Good/Fair/Poor } \\
\text { Self-Reported } \\
\text { Health (versus } \\
\text { Excellent/Very } \\
\text { Good) }\end{array}$ & 34.7 & 0.92 & $0.88,0.95$ & $<0.001$ & -1.8 & 214,510 \\
\hline
\end{tabular}

Notes: All analyses compare pre-post changes in the outcomes for Massachusetts versus other New England states, for the years 2001-2005 versus 2007-2010. Data are from the Current Population Survey (CPS) for uninsured, and from the Behavioral Risk Factor and Surveillance System (BRFSS) for the remaining measures. Sample sizes for BRFSS items differ primarily due to changes in which years of the survey each item was asked and small differences in item non-response. Adjusted model controls for age, sex, race, ethnicity/household income (as percentage of the federal poverty level), employment status, year, and state of residence. Absolute change calculated using change in predicted probabilities. 
Figure 1: Unadjusted Mortality Rates for Adults (20-64) from 2001-2010, in Massachusetts versus Control Group

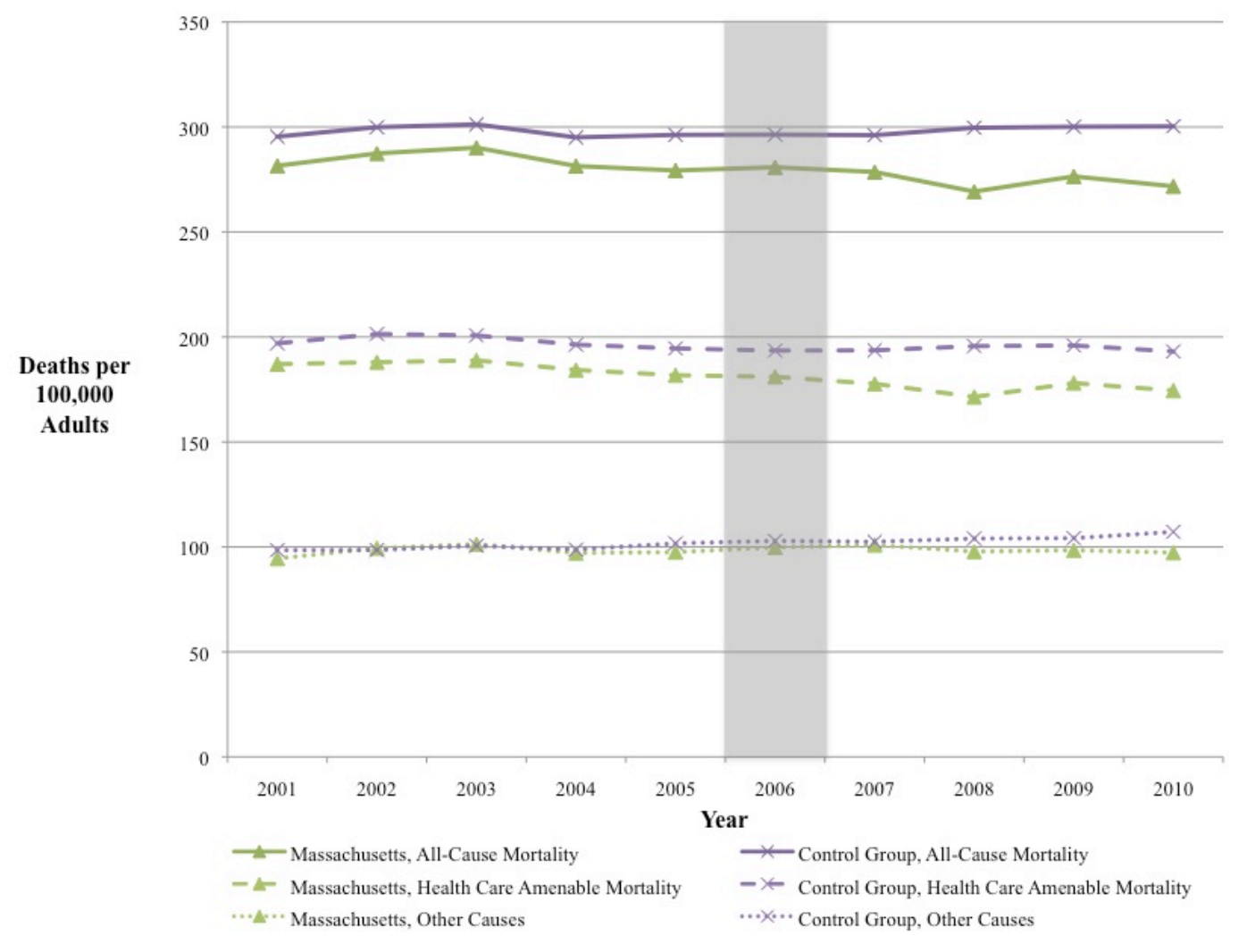

Notes:

Gray band designates the beginning of the Massachusetts state health reform, implemented starting in July 2006. "Healthcare Amenable Mortality" is as defined in Appendix Table 1, with "other causes" containing all other causes of death not included in that definition. 


\section{Supplemental Appendix to \\ "Changes in Mortality After Massachusetts Health Care Reform" \\ Sommers, Long, and Baicker, Annals of Internal Medicine}

\section{Details of the Mortality Data Source and Sample Size}

The Compressed Mortality File is a county-level database containing information on all U.S. deaths in the prior year, and information on the county-specific population by various demographic features. The database is collected and made publicly available by the National Center for Health Statistics at the Centers for Disease Control and Prevention (CDC), at the following website: http://wonder.cdc.gov/mortSQL.html. ${ }^{1}$ However, the publicly-available version suppresses death counts less than 10, so we obtained access under a data-use agreement with the CDC to the full non-suppressed dataset, which we used for our mortality analyses. ${ }^{2}$

Mortality information was obtained directly from death certificates. Population information came from the U.S. Census Bureau, providing information on each county's population by sex, age, ethnicity, and race. Year-specific county-level poverty rates, median income, unemployment, and Latino percentage of the population all came from the Area Resource File (ARF). ${ }^{3}$ Data from 2010 economic measures were not available in the most recent ARF release at the time of this analysis, so we carried forward 2009 values; our results were essentially unchanged when we excluded 2010 data.

In our baseline analysis, our sample size was defined by the following equation: $\mathrm{N}=\#$ counties $* 9$ years $* 2$ sexes $* 4$ age groups $* 4$ races

For Massachusetts, this yielded a possible 4032 county-level observations (for 14 counties); however, 47 of these combinations had 0 population members, meaning there was no one of that age-race-sex combination in a county in a particular year. The overall sample for Massachusetts in our analysis was therefore $\mathrm{N}=3,985$ observations.

We did not include Latino ethnicity as a stratification variable in our primary analysis, since ethnicity data are unknown for a portion of deaths in the mortality dataset and lack a corresponding population estimate needed to calculate a death rate. Instead, we adjusted for Latino ethnicity at the county level, as in a previous similar analysis of CDC data. ${ }^{4}$ In a sensitivity analysis, we included Latino ethnicity as a stratification variable and excluded those deaths for whom ethnicity was unknown, and the results were quite similar. Our preferred model used county-level data because it allowed us to use the richest set of economic indicators (county and year specific unemployment, median income, and poverty rate), and we felt that these potential confounders represented the greatest threat to the study's internal validity. Countylevel analyses also allowed us to examine subgroups to assess the plausibility of the causal mechanism implied by our findings - we were able to look differentially at mortality declines by county household income and baseline rates of health insurance coverage.

\section{Definitions and Analyses of Deaths Amenable to Health Care}

We adapted previous work by Nolte \& McKee $(2003,2008,2011)^{12-14}$ defining mortality amenable to medical care (Appendix Table 1). Our definition was more inclusive, and included all infectious and malignant causes of death (rather than a subset), congestive heart failure, and certain treatable arrhythmias. We also removed several diagnoses less relevant to our study population (e.g., congenital cardiac malformations). Our overall results were similar using both definitions: the post-reform relative mortality decline using the Nolte \& McKee measure was $5.5 \%(95 \%$ CI $-8.9,-2.1, p=0.002)$, from a baseline of 99 per 100,000; the estimate using our 
revised criteria was $-4.5 \%(95 \% \mathrm{CI}-6.2,-2.7, \mathrm{p}<0.001)$. Non-amenable deaths using our definition did not significantly decline, with an estimate of $-2.0 \%(95 \% \mathrm{CI}-5.5,1.5, \mathrm{p}=0.26)$.

\section{Details of the Propensity Score Approach}

The propensity score (PS) method used here is an adapted version of the approach used in non-randomized clinical trials of interventions such as a medical treatment, and is also analogous to the notion of a synthetic control group as outlined by Abadie and colleagues. ${ }^{5}$ We used a logistic regression model with multiple predictor variables to predict the outcome, which is the "treatment condition" - in this case, being a county in Massachusetts. Massachusetts counties have an outcome $=1$, and all other U.S. counties $=0$. The following variables were used to calculate the propensity scores: county-level information on race, ethnicity, age, sex, poverty rate, median household income, unemployment rate, uninsured rate prior in 2005, and annual baseline mortality rate from 2001-2006. The analysis was conducted at the county level, weighted for the size of each county's non-elderly adult population. Fitted values were then obtained for each non-Massachusetts county, indicating a "propensity" (or more precisely, a similarity index) to Massachusetts. There was significant overlap: the PS range for Massachusetts counties was from 0.00001 to 0.72 , and for non-Massachusetts control counties from essentially $0\left(1.21 \times 10^{-27}\right)$ to 0.99 . Then, using the propensity score, we identified the quartile of national counties that most closely resembled the overall population of Massachusetts' 14 counties. Table 2 shows that this approach achieved excellent balance, with no statistically significant differences in population characteristics between counties in the control group and those in Massachusetts.

Our approach differed somewhat from more traditional PS approaches. Unlike a typical PS analysis of a patient-level clinical intervention (where each observation is equal sized), our unit of analysis for the mortality data is the county, where population size varies dramatically across each unit, and where our treatment condition (Massachusetts) has just 14 counties. For these reasons, when we use a traditional PS method such as 2:1 nearest-neighbor matching, ${ }^{6}$ we end up with an underpowered sample (42 counties total), which is particularly limiting for potential subgroup analyses. We also considered a traditional PS regression adjustment strategy, using the full overlapping U.S. sample of counties, with direct adjustment for propensity scores in 10 deciles. $^{7}$ This resulted in similar overall estimates as our preferred baseline model, though the differences in baseline trends in mortality for the U.S. as a whole versus Massachusetts (Appendix Table 3) [even after PS decile adjustment] suggest that this is a less convincing control group for a quasi-experimental approach than our primary specification. However, it is reassuring that our main findings of relative mortality reductions in Massachusetts compared the control group were consistent across all three approaches (Appendix Table 4).

\section{Regression Models and Sensitivity Analyses}

Baseline GLM Model

The baseline analysis used a generalized linear model (GLM) with negative binomial family and a log link, with population size as the exposure variable, and the following equation:

$$
\begin{gathered}
\text { Death }_{i j k l t}=\beta_{0}+\beta_{M} \text { MassReform }_{l t}+\beta_{1} X_{i j k}+\beta_{2} \text { County-Level Factors }_{l t} \\
+\mu \text { Year }_{t}+\Omega \text { State }_{l}+\varepsilon_{i j k l t}
\end{gathered}
$$

where $i$ indexed age, $j$ race, $k$ sex, $l$ county, and $t$ year. $X_{i j k}$ was a vector of demographics (age group, race, and sex). County-Level Factors included county-year-specific poverty rate, median 
income (in 2010 inflation-adjusted dollars), unemployment rate, and percentage of the population that is Latino. $\mu$ was a vector of year fixed effects, and $\Omega$ is a vector of state fixed effects. The coefficient of interest was $\beta_{M}$, which captures the effect of living in Massachusetts after the year 2006. The regression used Huber-White robust standard errors clustered at the state level and was weighted for population size.

Pre-Reform Trend Analyses (Sample limited to 2001-2006):

To test for divergence in mortality trends prior to Massachusetts' health reform, we used a generalized linear model (GLM) with negative binomial family and a log link, with population size as the exposure variable, and the following equation:

$$
\begin{aligned}
\text { Deaths }_{i j k l t}=\beta_{0}+\beta_{1} X_{i j k} & +\beta_{2} \text { County-Level Factors }_{l t}+\mu \text { Time Trend }_{t} \\
& +\Phi \text { Massachusetts }_{S} * \text { Time Trend }_{t}+\Omega \text { State }_{l}+\varepsilon_{i j k l s t}
\end{aligned}
$$

where $\mu$ was a linear time trend, and $\Phi$ was a Massachusetts-specific time trend, created by the interaction between the Time Trend and Massachusetts. The quadratic time trend analyses simply replaced the linear time trend with time-trend squared, for both $\mu$ and $\Phi$. The other terms were defined as in Equation (1). The results are presented in Appendix Table 3.

\section{Linear Model}

For comparability to prior similar analyses of insurance expansions and ease of interpretation of absolute changes, ${ }^{4}$ we also tested the following linear model using the mortality rate per 100,000 as the outcome variable:

$$
\begin{aligned}
\text { Mortality Rate }_{i j k l t}=\beta_{0} & +\beta_{M} \text { MassReform }_{l t}+\beta_{1} X_{i j k}+\beta_{2} \text { County-Level Factors }_{l t} \\
& +\mu \text { Year }_{t}+\Omega \text { County }_{l}+\varepsilon_{i j k l t}
\end{aligned}
$$

where $\Omega$ was a vector of county fixed effects (GLM models with county fixed effects did not converge due to the high number of counties, requiring the use of state fixed effects in Equation 1; the linear model enabled us to adjust for time-invariant features at the county level). The other terms were defined as in Equation (1). The results are presented in Appendix Table 4.

Elderly Adults as an Additional Control Group for Non-Elderly Adults in Massachusetts

To test for changes in Massachusetts' health reform for non-elderly (20-64) versus elderly adults (65 and over), we used a generalized linear model (GLM) with negative binomial family and a log link, with population size as the exposure variable, and the following equation:

$$
\begin{aligned}
\text { Deaths }_{i j k l t}=\beta_{0}+\beta X_{i j k} & +\beta_{1} \text { Post-Reform }_{t} * \text { Non-Elderly }_{i} \\
& +\beta_{2} \text { Non-Elderly }_{i} * \text { Massachusetts }_{l} \\
& +\beta_{3} \text { Post-Reform }_{t} * \text { Massachusetts }_{l} \\
& +\beta_{4} \text { Post-Reform }_{t} * \text { Massachusetts }_{l} * \text { Non-Elderly }_{i} \\
& +\beta_{5} \text { County-Level Factors }_{l t}+\mu \text { Year }_{t}+\Omega \text { State }_{l}+\varepsilon_{i j k l s t} \quad \text { Equation (4) }
\end{aligned}
$$

where direct effects for Massachusetts and Post-Reform were captured by the state fixed effects and year fixed effects, respectively. The direct effect of Non-Elderly was captured by the age dummy variables, which include a cut-point at 65 years. $\beta_{3}$ measures the relative change in mortality after reform among elderly adults in Massachusetts compared to elderly adults in the control states. The coefficient of interest was $\beta_{4}$, which measured the relative change in mortality after health reform among non-elderly adults (20-64) in Massachusetts versus non-elderly adults 
in the control states, net of the relative change in mortality among elderly adults $(65+)$. The other terms were defined as in Equation (1). This is also known as a "differences-in-differences-indifferences" analysis. The results are presented in Appendix Table 5.

Subgroup Analysis

To test for changes in Massachusetts' health reform among subgroups of adults ages 20-64, we used a generalized linear model (GLM) with negative binomial family and a log link, with population size as the exposure variable, and the following equation:

$$
\begin{aligned}
\text { Deaths }_{i j k l t}=\beta_{0}+\beta X_{i j k} & +\beta_{1} \text { Post-Reform }_{t} * \text { Subgroup }_{A} \\
& +\beta_{2} \text { Subgroup }_{A} * \text { Massachusetts }_{l} \\
& +\beta_{3} \text { Post-Reform }_{t} * \text { Massachusetts }_{l} * \text { Subgroup }_{B} \\
& +\beta_{4} \text { Post-Reform }_{t} * \text { Massachusetts }_{l} * \text { Subgroup }_{A} \\
& +\beta_{5} \text { County-Level Factors }_{l t}+\mu \text { Year }_{t}+\Omega \text { State }_{l}+\varepsilon_{i j k l s t} \quad \text { Equation (5) }
\end{aligned}
$$

where direct effects for Massachusetts and Post-Reform were captured by the state fixed effects and year fixed effects, respectively. The direct effect of Subgroup Sersus Subgroup $_{B}$ was included in the vector of covariates $X_{i j k}$. $\beta_{3}$ measured the relative change in mortality after reform among Subgroup in Massachusetts, compared to Subgroup $_{A}$ in control states. $\beta_{4}$, measured the relative change in mortality after health reform among $\operatorname{Subgroup}_{B}$ in Massachusetts versus Subgroup $_{B}$ in control states. The other terms were defined as in Equation (1). This approach allowed for direct post-estimation testing for between-group differences comparing $\beta_{3}$ and $\beta_{4}$. The results are presented in Appendix Table 5.

Secondary Outcomes - Coverage, Access to Care, and Health Status:

To test for changes in secondary outcomes using the CPS and BRFSS, we used a generalized linear model (GLM) with logit link, and Huber-White robust standard errors clustered at the state level, with the following equation:

$\operatorname{Pr}\left(\right.$ Outcome $\left._{i s t}\right)=\beta_{0}+\beta_{M}$ MassReform $_{s t}+\beta_{1} X_{i t}+\mu$ Year $_{t}+\Omega$ State $_{s}+\pi$ Year $_{t}+\varepsilon_{i s t}$

Equation (6)

where $i$ indexed individuals, $s$ states, and $t$ year. $X_{i}$ was a vector of demographics (age, race/ethnicity, gender, family income as percentage of the federal poverty level, and employment status). $\mu$ was a vector of year fixed effects, and $\Omega$ was a vector of state fixed effects. The coefficient of interest was $\beta_{M}$, which captured the effect of living in Massachusetts after the year 2006. Analyses of secondary outcomes (uninsured, cost-related barriers to care, usual source of care, checkup within the past year, and good/fair/poor self-reported health) all used Equation 6, with the only difference being the dependent variable.

\section{Estimating the Magnitude of Mortality Changes Related to Coverage Expansion}

Appendix Table 7 presents calculations illustrating the implications of our results for individual-level changes in mortality due to the coverage expansion in Massachusetts. This calculation used statistics from various sources: the total non-elderly adult population of Massachusetts (4.0 million) comes from the Kaiser Commission, ${ }^{8}$ and the baseline mortality rate in this population $(283 / 100,000=0.283 \%)$ comes from Table 3 . We used the total of $6.8 \%$ new insurance enrollees estimated in Table 5. Next we assumed a 30\% individual mortality reduction of acquiring insurance, based on prior research. ${ }^{9,10}$ Then, we calculated what baseline mortality 
rate was necessary among new insurance enrollees to have all of the above parameters yield a population-wide mortality reduction due to health reform equal to the result in Table $3(2.9 \%)$. The overall conclusion is that the baseline mortality for new insurance enrollees must be $0.400 \%$ $(400 / 100,000)$ to produce a population-wide mortality reduction from the state's health reform that is consistent with our findings in Table 3.

\section{Sensitivity of Results to Omitted Confounders}

To assess the sensitivity of our mortality results to the possibility of an omitted confounder, we followed the approach in Vanderweele et al. (2011). ${ }^{11}$ We posited the existence of an unmeasured confounder variable $U$ with a prevalence $10 \%$ higher in the Massachusetts population after its health reform than before health reform, with no comparable change in $U$ in the control group during this period. For this confounder to explain the full absolute decline in estimated population mortality $(-8.2$ deaths per 100,000$)$, the baseline mortality reduction for those with $U=1$ compared to the general population $(U=0)$ would need to be $X$, where $0.10 *-X$ $=-8.2 / 100,000$.

Solving this equation, $X=82$ / 100,000. This would amount to a $29 \%$ lower mortality rate for those with trait $U$ than for the general Massachusetts population $(82 / 283=29 \%)$.

Overall, we would need to posit a fairly high-prevalence of an unmeasured confounder that increased substantially after reform only in Massachusetts $(+10$ percent of the population) and that has a sizable impact on mortality, cutting it by nearly $30 \%$ compared to baseline. Other than the major change in health insurance coverage during this period, it is difficult to identify what such a factor might have been that was not already included in our regression covariates and that did not also affect the elderly population. 


\section{Appendix Table 1: Definitions of Deaths Amenable to Health Care}

\begin{tabular}{|c|c|c|c|}
\hline Condition(s) & ICD-10 Codes & $\begin{array}{c}\text { Nolte \& } \\
\text { McKee } \\
\text { Definition }\end{array}$ & $\begin{array}{c}\text { Authors' } \\
\text { Revised } \\
\text { Definition }\end{array}$ \\
\hline Infectious \& Parasitic Diseases $(A L L)$ & A00-B99 & & $\mathrm{X}$ \\
\hline -Tuberculosis & A16-19, B90 & $\mathrm{X}$ & $\mathrm{X}$ \\
\hline $\begin{array}{l}\text {-Other specific infections (diphtheria, tetanus, septicemia, } \\
\text { poliomyelitis, whooping cough, measles) }\end{array}$ & $\begin{array}{l}\text { A35-A37, A40-41, } \\
\text { A } 80, \text { B } 05\end{array}$ & $\mathrm{X}$ & $\mathrm{X}$ \\
\hline Neoplasms $(A L L)$ & C00-D48 & & $\mathrm{X}$ \\
\hline -Malignant neoplasm of colon and rectum & $\mathrm{C} 18-\mathrm{C} 21$ & $\mathrm{X}$ & $\mathrm{X}$ \\
\hline -Malignant neoplasm of skin & C44 & $\mathrm{X}$ & $\mathrm{X}$ \\
\hline -Malignant neoplasm of breast & $\mathrm{C} 50$ & $\mathrm{X}$ & $\mathrm{X}$ \\
\hline -Malignant neoplasm of cervix or uterus & $\mathrm{C} 53-\mathrm{C} 55$ & $\mathrm{X}$ & $\mathrm{X}$ \\
\hline -Malignant neoplasm of testis & C62 & $\mathrm{X}$ & $\mathrm{X}$ \\
\hline -Hodgkin's disease & $\mathrm{C} 81$ & $\mathrm{X}$ & $\mathrm{X}$ \\
\hline -Leukemia & C91-C95 & $\mathrm{X}$ & $\mathrm{X}$ \\
\hline Disorders of thyroid gland & E00-E07 & $\mathrm{X}$ & $\mathrm{X}$ \\
\hline Diabetes Mellitus & E10-E14 & $\mathrm{X}$ & $\mathrm{X}$ \\
\hline Epilepsy & G40-G41 & $\mathrm{X}$ & $\mathrm{X}$ \\
\hline Chronic rheumatic heart diseases & I05-I09 & $\mathrm{X}$ & $\mathrm{X}$ \\
\hline Hypertensive diseases & $\mathrm{I} 10-\mathrm{I} 13, \mathrm{I} 15$ & $\mathrm{X}$ & $\mathrm{X}$ \\
\hline Ischemic heart diseases & I20-I25 & $\mathrm{X}$ & $\mathrm{X}$ \\
\hline Cardiomyopathy & I42 & & $\mathrm{X}$ \\
\hline Atrial fibrillation and flutter & I48 & & $\mathrm{X}$ \\
\hline Other cardiac arrhythmias & I49 & & $\mathrm{X}$ \\
\hline Heart failure & $\mathrm{I} 50$ & & $\mathrm{X}$ \\
\hline Cerebrovascular diseases & I60-I69 & $\mathrm{X}$ & $\mathrm{X}$ \\
\hline All respiratory diseases & J00-J98 & $\mathrm{X}$ & $\mathrm{X}$ \\
\hline Gastric and duodenal ulcers & K25-K27 & $\mathrm{X}$ & $\mathrm{X}$ \\
\hline Gastrojejunal ulcers & K28 & & $\mathrm{X}$ \\
\hline Diseases of appendix & K35-K38 & $\mathrm{X}$ & $\mathrm{X}$ \\
\hline Hernia & K40-K46 & $\mathrm{X}$ & $\mathrm{X}$ \\
\hline Diseases of gallbladder and biliary tract & K80-K83 & $\mathrm{X}$ & $\mathrm{X}$ \\
\hline Acute pancreatitis & K85 & & $\mathrm{X}$ \\
\hline Infections of the skin and subcutaneous tissue & L00-L08 & & $\mathrm{X}$ \\
\hline Infectious arthropathies & M00-M02 & & $\mathrm{X}$ \\
\hline Glomerular diseases & N00-N07 & $\mathrm{X}$ & $\mathrm{X}$ \\
\hline Renal tubulo-interstitial diseases & N10-N15 & & $\mathrm{X}$ \\
\hline Renal failure & N17-N19 & $\mathrm{X}$ & $\mathrm{X}$ \\
\hline Unspecified contracted kidney, small kidney unknown cause & $\mathrm{N} 26-\mathrm{N} 27$ & $\mathrm{X}$ & \\
\hline Hyperplasia of prostate & $\mathrm{N} 40$ & $\mathrm{X}$ & \\
\hline Pregnancy, childbirth and the puerperium & O00-099 & $\mathrm{X}$ & $\mathrm{X}$ \\
\hline Congenital malformations originating in the perinatal period & $\mathrm{P} 00-\mathrm{P} 96$ & $\mathrm{X}$ & \\
\hline Misadventures to patients during surgical and medical care & Y60-Y69, Y83-Y84 & $\mathrm{X}$ & $\mathrm{X}$ \\
\hline
\end{tabular}




\section{Appendix Table 2: Variables Used to Calculate Propensity Score}

\begin{tabular}{|l|c|c|c|c|}
\hline Variable & Odds Ratio & $\mathbf{9 5 \%}$ Confidence Interval & P Value \\
\hline Ages 20-34 & 0.7959 & 0.5674 & 1.1163 & 0.186 \\
\hline Ages 35-44 & 0.7819 & 0.4211 & 1.4519 & 0.44 \\
\hline Ages 45-54 & 0.4389 & 0.1509 & 1.2769 & 0.131 \\
\hline Ages 55-64 & 1.0000 & -- & -- & reference \\
\hline Male & 0.1595 & 0.0564 & 0.4507 & 0.001 \\
\hline White & 0.9879 & 0.9421 & 1.0360 & 0.62 \\
\hline Black & 0.8450 & 0.6931 & 1.0302 & 0.096 \\
\hline Other Race & 1.0000 & -- & -- & reference \\
\hline Latino & 0.9868 & 0.8929 & 1.0907 & 0.80 \\
\hline Poverty Rate & 0.9846 & 0.7848 & 1.2352 & 0.89 \\
\hline Median Household Income & 1.0000 & 0.9999 & 1.0001 & 0.65 \\
\hline Unemployment Rate & 1.4645 & 1.0873 & 1.9726 & 0.012 \\
\hline Percent Uninsured & 0.6345 & 0.5311 & 0.7580 & $<0.001$ \\
\hline Mortality Rate 2001 & 0.9934 & 0.9762 & 1.0108 & 0.45 \\
\hline Mortality Rate 2002 & 1.0134 & 0.9999 & 1.0271 & 0.052 \\
\hline Mortality Rate 2003 & 1.0100 & 0.9982 & 1.0220 & 0.097 \\
\hline Mortality Rate 2004 & 1.0027 & 0.9930 & 1.0126 & 0.58 \\
\hline Mortality Rate 2005 & 0.9841 & 0.9723 & 0.9960 & 0.009 \\
\hline Mortality Rate 2006 & 0.9870 & 0.9670 & 1.0074 & 0.21 \\
\hline Constant Term & $2.23 \mathrm{E}+56$ & $6.83 \mathrm{E}+38$ & $7.31 \mathrm{E}+73$ & $<0.001$ \\
\hline
\end{tabular}

Notes: Based on population-weighted county-level logistic regression model using 2000-2006 data for adults ages 20-64. Mortality rates were expressed as deaths per 100,000 adults, and median household income in 2010 inflation-adjusted dollars. All other variables are expressed in percentage points $(0-100)$. 


\section{Appendix Table 3: Tests of Pre-Reform Mortality Trends (per 100,000 Adults) in Massachusetts versus Control Group and Overall United States}

\begin{tabular}{|l|ccc|cr|}
\hline $\begin{array}{l}\text { Comparison Group } \\
\text { Relative to } \\
\text { Massachusetts }\end{array}$ & $\begin{array}{c}\text { Differential } \\
\text { Trend for } \\
\text { Massachusetts } \\
\text { vs. Control } \\
\text { Group }\end{array}$ & 95\% CI & P value & $\begin{array}{c}\text { Differential } \\
\text { Trend for } \\
\text { Massachusetts } \\
\text { vs. Other U.S. } \\
\text { States }\end{array}$ & $\begin{array}{c}\text { 95\% CI } \\
\text { value }\end{array}$ \\
\hline $\begin{array}{l}\text { Linear Time Trend, } \\
\text { 2001-2006 }\end{array}$ & -1.1 & $-2.4,0.3$ & 0.120 & -1.9 & $-2.9,-0.8$ \\
\hline $\begin{array}{l}\text { Quadratic Time Trend, } \\
\text { 2001-2006 }\end{array}$ & -0.15 & $-0.34,0.04$ & 0.116 & -0.27 & $-0.42,-0.12$ \\
\hline
\end{tabular}




\section{Appendix Table 4: \\ Sensitivity Analyses of Estimates of Mortality Changes After Massachusetts' Health Reform Among Adults 20-64 (2001-2010)}

\begin{tabular}{|c|c|c|c|}
\hline MODEL & $\begin{array}{l}\text { Difference in } \\
\text { Change, } \\
\text { Massachusetts } \\
\text { vs. Control } \\
\text { Group } \\
\end{array}$ & $95 \% \mathrm{CI}$ & $P$ value \\
\hline \multicolumn{4}{|l|}{$\begin{array}{l}\text { Alternative Propensity Score (PS) Methods and Control } \\
\text { Groups, All-Cause Mortality }\end{array}$} \\
\hline $\begin{array}{l}\text { PS Regression Adjustment, in deciles, for all U.S. counties in } \\
\text { areas of PS overlap with Massachusetts counties }\end{array}$ & $-2.5 \%$ & $-4.0,-1.0$ & 0.001 \\
\hline PS Matching (2:1 control:treatment)* & $-8.2 \%$ & $-12.6,-3.7$ & $<0.001$ \\
\hline $\begin{array}{l}\text { Baseline Model, excluding states with major Medicaid } \\
\text { expansions } \dagger\end{array}$ & $-3.3 \%$ & $-5.9,-0.7$ & 0.012 \\
\hline \multicolumn{4}{|l|}{ Baseline Model, with Alternative Standard Errors } \\
\hline Unadjusted all-cause mortality, county-level clustering & $-4.2 \%$ & $-7.2,-1.2$ & 0.006 \\
\hline Adjusted all-cause mortality, county-level clustering & $-2.9 \%$ & $-5.5,-0.2$ & 0.033 \\
\hline $\begin{array}{l}\text { Unadjusted health-care amenable mortality, county-level } \\
\text { clustering }\end{array}$ & $-4.3 \%$ & $-7.8,-0.8$ & 0.015 \\
\hline Adjusted health-care amenable mortality, county-level clustering & $-4.5 \%$ & $-8.4,-0.5$ & 0.028 \\
\hline \multicolumn{4}{|l|}{ Linear Model, with Death Rate (per 100,000$)$ as Outcome } \\
\hline Unadjusted all-cause mortality & -11.4 & $-22.3,-0.5$ & 0.040 \\
\hline Adjusted all-cause mortality & -6.4 & $-10.8,-2.0$ & 0.006 \\
\hline Adjusted all-cause mortality, with county fixed effects* & -9.3 & $-16.7,-1.9$ & 0.014 \\
\hline Unadjusted health-care amenable mortality & -7.2 & $-12.3,-2.0$ & 0.007 \\
\hline Adjusted health-care amenable mortality & -4.5 & $-8.3,-0.6$ & 0.024 \\
\hline $\begin{array}{l}\text { Adjusted health-care amenable mortality, with county fixed } \\
\text { effects* }\end{array}$ & -7.5 & $-10.2,-4.7$ & $<0.001$ \\
\hline \multicolumn{4}{|l|}{ State-Level Analyses§ } \\
\hline Unadjusted state-level mortality & $-4.1 \%$ & $-7.7,-0.5$ & 0.025 \\
\hline Adjusted state-level mortality & $-2.3 \%$ & $-5.1,0.5$ & 0.103 \\
\hline Unadjusted state-level health-care amenable mortality & $-4.2 \%$ & $-6.8,-1.6$ & 0.002 \\
\hline Adjusted state-level health-care amenable mortality & $-4.5 \%$ & $-6.5,-2.6$ & $<0.001$ \\
\hline \multicolumn{4}{|l|}{$\begin{array}{l}\text { Alternative Time Frame or Analytic Frame, All-Cause } \\
\text { Mortality }\end{array}$} \\
\hline Include 2006 as the first post-reform year & $-3.5 \%$ & $-5.3,-1.8$ & $<0.001$ \\
\hline Interrupted times series (pre-reform vs. post-reform trend)\# & $-1.0 \%$ per year & $-1.8,-0.3$ & 0.006 \\
\hline Pre-reform versus post-reform pooled data (instead of yearly) & $-3.1 \%$ & $-5.2,-1.1$ & 0.003 \\
\hline $\begin{array}{l}\text { Individual-level Latino ethnicity (omitting those with ethnicity } \\
\text { unknown) }\end{array}$ & $-3.0 \%$ & $-4.7,-1.4$ & $<0.001$ \\
\hline
\end{tabular}

Notes:

* The baseline GLM model uses state level fixed effects; due to the number of counties in the baseline sample, the GLM models do not converge when using county fixed effects. For the PS match model with a much smaller number of counties, and in the linear models, we are able to adjust for time-invariant county-level features using county fixed effects. 
$\dagger$ Excluded states were Arizona, Illinois, Maine, and New York, which all implemented large Medicaid expansions to adults between 2001 and $2010 .^{15}$

$\S$ Analysis conducted using the same control group but with mortality data aggregated to the state level (using stateyear-age-sex-race cells as the unit of analysis).

\# Replaces year fixed effects with a linear time trend, and replaces Massachusetts Post Reform binary variable with an interaction term between Massachusetts and Years Since Reform (i.e., year - 2006).

I This model adjusts directly for Latino ethnicity, which requires omitting from the sample any deaths with "unknown" ethnicity, since the dataset has no corresponding population denominator for that group necessary to calculate a death rate. This accounts for $0.3 \%$ of deaths among 20-64 years old nationally; omitting these deaths results in a reduction in the estimated national mortality rate of -1.2 deaths per 100,000. 


\section{Appendix Table 5: Analyses of Mortality Changes After Massachusetts' Health Reform Among Adults 20-64, Using Elderly Adults as an Additional Control Group (2001-2010)}

\begin{tabular}{|c|c|c|c|c|c|c|}
\hline \multirow{2}{*}{$\begin{array}{l}\text { OUTCOME and Variable } \\
\text { ALL CAUSE MORTALITY }\end{array}$} & \multicolumn{3}{|c|}{ Negative Binomial GLM } & \multicolumn{3}{|c|}{$\begin{array}{c}\text { Linear Regression of } \\
\text { Ln(Death Rate), with County } \\
\text { Fixed Effects\# }\end{array}$} \\
\hline & Coefficient & $95 \%$ CI & $\begin{array}{c}P \\
\text { value }\end{array}$ & Coefficient & $95 \% \mathrm{CI}$ & $\begin{array}{c}P \\
\text { value }\end{array}$ \\
\hline Post-Reform*Massachusetts*Non-Elderly $\dagger$ & -3.3 & $-6.6,0.2$ & 0.066 & -3.9 & $-7.8,-0.1$ & 0.046 \\
\hline Post-Reform*Massachusetts $\S$ & 0.1 & $-2.5,2.7$ & 0.93 & -0.3 & $-1.5,0.9$ & 0.61 \\
\hline $\begin{array}{l}\text { HEALTH-CARE AMENABLE } \\
\text { MORTALITY }\end{array}$ & Coefficient & $95 \% \mathrm{CI}$ & $\begin{array}{c}P \\
\text { value }\end{array}$ & Coefficient & $95 \% \mathrm{CI}$ & $\begin{array}{c}P \\
\text { value }\end{array}$ \\
\hline Post-Reform*Massachusetts*Non-Elderl & -4.9 & $-7.1,-2.7$ & $<0.001$ & -5.3 & $-7.9,-2.7$ & $<0.001$ \\
\hline Post-Reform*Massachusetts $\S$ & 0.2 & $-2.4,2.7$ & 0.90 & -1.1 & $-2.3,0.2$ & 0.096 \\
\hline
\end{tabular}

\section{Notes:}

$\dagger$ Measures the differential change for non-elderly adults in Massachusetts relative to the control group, subtracting out the analogous changes among elderly adults.

$\S$ Measures the differential change for elderly adults in Massachusetts, relative to elderly adults in the control group. \# The baseline GLM model uses state level fixed effects; due to the number of counties in the baseline sample, the GLM models do not converge when using county fixed effects. For the linear model, we are able to adjust for timeinvariant county-level features using county fixed effects. 


\section{Appendix Table 6: Sensitivity Analyses of Access to Care and Health Status, After Massachusetts' Health Reform}

\begin{tabular}{|c|c|c|c|c|c|c|c|}
\hline \multirow[b]{2}{*}{ OUTCOME } & \multicolumn{4}{|c|}{$\begin{array}{c}\text { Logit GLM, Robust Standard Errors, } \\
\text { No Clustering }\end{array}$} & \multicolumn{3}{|c|}{$\begin{array}{l}\text { Linear Probability Model, Robust } \\
\text { Standard Errors with State } \\
\text { Clustering }\end{array}$} \\
\hline & $\begin{array}{c}\text { Adjusted } \\
\text { Odds Ratio, } \\
\text { Post- } \\
\text { Massachusetts } \\
\text { Health } \\
\text { Reform }\end{array}$ & $95 \%$ CI & $\begin{array}{c}P \\
\text { value }\end{array}$ & $\begin{array}{c}\text { Absolute } \\
\text { Change in } \\
\text { Predicted } \\
\text { Probability } \\
\text { (percentage } \\
\text { points) }\end{array}$ & $\begin{array}{l}\text { Difference in } \\
\text { Change, } \\
\text { Massachusetts } \\
\text { vs. Control } \\
\text { Group } \\
\text { (percentage } \\
\text { points) }\end{array}$ & $95 \%$ CI & $\begin{array}{c}\mathbf{P} \\
\text { value }\end{array}$ \\
\hline Uninsured & 0.43 & $\begin{array}{l}0.37 \\
0.49\end{array}$ & $<0.001$ & -6.8 & -6.8 & $-7.4,-6.3$ & $<0.001$ \\
\hline $\begin{array}{l}\text { Delayed Care } \\
\text { Due to Cost in } \\
\text { Past Year }\end{array}$ & 0.78 & $\begin{array}{l}0.70 \\
0.87\end{array}$ & $<0.001$ & -2.0 & -2.0 & $-3.3,-0.8$ & 0.009 \\
\hline $\begin{array}{l}\text { No Usual Source } \\
\text { of Care }\end{array}$ & 0.84 & $\begin{array}{l}0.77 \\
0.91\end{array}$ & $<0.001$ & -1.9 & -1.7 & $-2.6,-0.8$ & 0.006 \\
\hline $\begin{array}{l}\text { No Preventive } \\
\text { Doctor's Visit in } \\
\text { Past Year }\end{array}$ & 0.82 & $\begin{array}{l}0.74 \\
0.91\end{array}$ & $<0.001$ & -4.0 & -3.8 & $-4.8,-2.8$ & $<0.001$ \\
\hline $\begin{array}{l}\text { Good/Fair/Poor } \\
\text { Self-Reported } \\
\text { Health (versus } \\
\text { Excellent/Very } \\
\text { Good) }\end{array}$ & 0.92 & $\begin{array}{l}0.86 \\
0.98\end{array}$ & 0.008 & -1.8 & -1.8 & $-2.9,-0.8$ & 0.007 \\
\hline
\end{tabular}

Notes: Analyses comparing these outcomes in Massachusetts to the propensity-score defined set of comparison counties (as in Tables 1-4) is not possible due to a lack of county-identifying information in these datasets. GLM $=$ Generalized Linear Model 


\section{Appendix Table 7: Calculation of Simulated Mortality Benefit from Massachusetts' Health Reform}

\begin{tabular}{|l|c|c|c|}
\hline \multicolumn{3}{|c|}{ PRE-REFORM } \\
\hline Group & N & Mortality Rate & Deaths \\
\hline New Insurance Enrollees & 272,000 & $0.400 \%$ & 1,088 \\
\hline All Other Adults & $3,728,000$ & $0.274 \%$ & 10,232 \\
\hline TOTAL & $4,000,000$ & $0.283 \%$ & 1,320 \\
\hline \multicolumn{2}{|c|}{ POST-REFORM } \\
\hline Group & N & Mortality Rate & Deaths \\
\hline New Insurance Enrollees & 272,000 & $0.280 \%$ & 762 \\
\hline All Other Adults & $3,728,000$ & $0.274 \%$ & 10,232 \\
\hline TOTAL & $4,000,000$ & $0.275 \%$ & 10,994 \\
\hline
\end{tabular}

Individual Mortality Reduction $=(0.400 \%-0.280 \%) / 0.400 \%=30 \%$

Population-Wide Mortality Reduction $=(11,320-10,994) / 11,320=2.9 \%$

Number Needed to Treat $=272,000 /(1088-762)=830$

Note:

See description of methods in Appendix. 


\section{Appendix Figure 1: Unadjusted Mortality Rates for Elderly Adults (65 and Older) from 2001-2010}

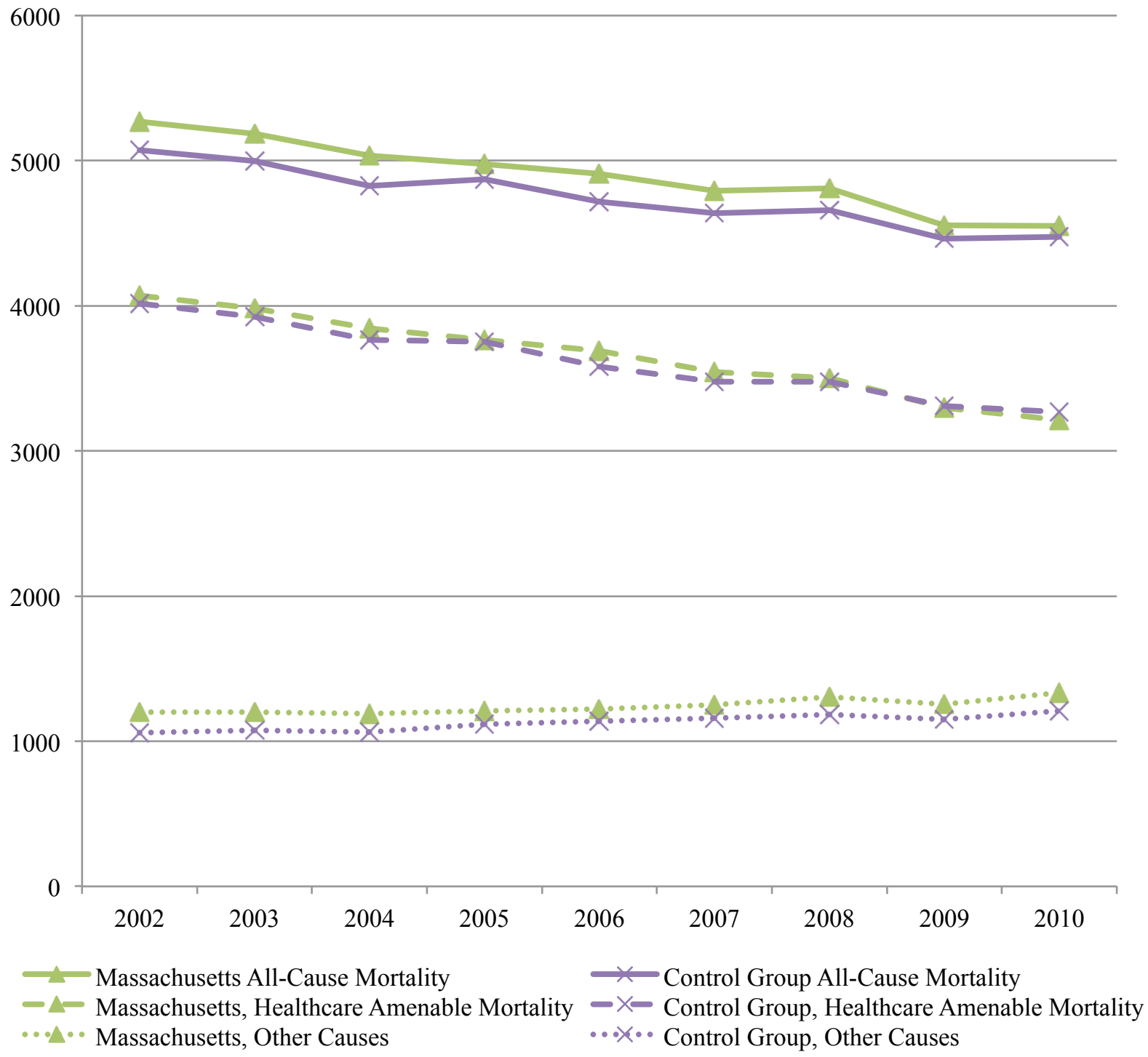




\section{Appendix References}

1. Compressed Mortality File. Centers for Disease Control and Prevention, 2013. (Accessed 10 February 2013, at http://www.cdc.gov/nchs/data access/cmf.htm\#database.)

2. National Center for Health Statistics. Compressed Mortality File, 1999-2010 (machine readable data file and documentation, CD ROM Series 20, No. 2P) as compiled from data provided by the 57 vital statistics jurisdictions through the Vital Statistics Cooperative Program. Hyattsville, Maryland. 2012.

3. Area Resource File (ARF). 2011-2012. US Department of Health and Human Services, Health Resources and Services Administration, Bureau of Health Professions, Rockville, MD.

4. Sommers BD, Baicker K, Epstein AM. Mortality and Access to Care among Adults after State Medicaid Expansions. N Engl J Med 2012.

5. Abadie A, Diamond A, Hainmueller J. Comparative Politics and the Synthetic Control Method. Cambridge, MA: Harvard Kennedy School; 2012.

6. Dhalla IA, Mamdani MM, Juurlink DN. Chlorthalidone versus hydrochlorothiazide. Ann Intern Med 2013;158:923-4.

7. Ray WA, Murray KT, Griffin MR, et al. Outcomes with concurrent use of clopidogrel and proton-pump inhibitors: a cohort study. Ann Intern Med 2010;152:337-45.

8. State Health Facts. Kaiser Commission on Medicaid and the Uninsured. 2013. Available at: http:/www.statehealthfacts.org/comparetable.jsp?typ=1\&ind=2\&cat=1\&sub=1

9. Care without coverage: too little, too late. Washington, D.C.: Institute of Medicine; 2002.

10. Hadley J. Sicker and poorer: the consequences of being uninsured. Medical Care Research and Review 2003;60:3S-75S.

11. Vanderweele TJ, Arah OA. Bias formulas for sensitivity analysis of unmeasured confounding for general outcomes, treatments, and confounders. Epidemiology 2011;22:42-52.

12. Nolte E, McKee CM. Measuring the health of nations: updating an earlier analysis. Health Aff (Millwood) 2008;27:58-71.

13. Nolte E, McKee M. Measuring the health of nations: analysis of mortality amenable to health care. Bmj 2003;327:1129.

14. Nolte E, McKee M. Variations in amenable mortality--trends in 16 high-income nations. Health Policy 2011;103:47-52.

15. Artiga S, Mann C. Coverage gains under recent Section 1115 waivers: a data update. Washington, D.C.: Kaiser Family Foundation; 2005. 